\title{
Voces libertarias: The Economic, Political and Social Discourse of Puerto Rican Anarchism, 1900 - 1917
}

\author{
Jorell A. Meléndez Badillo ${ }^{1}$
}

This essay intends to shed some light on the discourses elaborated by the anarchists in Puerto Rico at the turn of the twentieth century. The period studied is characterized by an accelerated change in the means of production, caused by the North American invasion, which is materialized through a kaleidoscope of vast complexity for the ascendant working class. It is through this reality that local anarchists tried to elaborate native postures in relation to their immediate historical reality from outside official circles. We will analyze their intellectual production in order to determine how these individuals tried to shape their own identity while creating transnational bonds with anarchists from the Caribbean, America, and Europe. [Article copies available for a fee from The Transformative Studies Institute. E-mail address: journal@transformativestudies.org Website: http://www.transformativestudies.org (C2012 by The Transformative Studies Institute. All rights reserved.]

KEYWORDS: Anarchism, Puerto Rico, Working class.

Over the past several years a debate has erupted inside international libertarian intellectual circles concerning the origins of anarchism. Many recent thinkers, such as George Woodcock and Peter Marshall, would agree with their predecessor Max Nettlau that the "history of the anarchist idea is inseparable from progressive developments and the aspiration towards liberty" (Nettlau 1977: 13). This view traces Anarchism's origin to thinkers such as Lao-Tse [607 b.c.], Zenón [342270 b.c.] and Carpócrates [II century], (Marshall 2008: 53; Cuevas Noa 2003: 43). On the other hand we find the position of Michael Schmidt and Lucien van der Walt, whose book Black Flame: The Revolutionary Class Politics of Anarchism and Syndicalism proposes Anarchism's

\footnotetext{
${ }^{1}$ Acknowledgements: The author would like to thank Luis Oyola, Zoraida López, Dianne Bras and Valeria Izquierdo with the help in the translation process. Address correspondence to: nopasaranjamas@gmail.com.
} 